\title{
ПОРІВНЯННЯ ПОКАЗНИКІВ ОРГАНІЗАЦІЙНОЇ РОБОТИ ПРИВАТНОГО ТА КОМУНАЛЬНОГО НЕКОМЕРЦЙНОГО КОНСУЛЬТАТИВНО-ДІАГНОСТИЧНИХ ЦЕНТРІВ
}

\author{
А. О. Боб므, О. О. Чукур ${ }^{1}$, В. В. Балогланова ${ }^{2}$ \\ ${ }^{1}$ Тернопільський національний медичний університет \\ імені І. Я. Горбачевського МОЗ Украӥни \\ ${ }^{2}$ Миколаӥвський обласний онкологічний диспансер
}

\begin{abstract}
Проведено порівняльний аналіз організації вторинної амбулаторної допомоги дорослому населенню м. Миколаєва у комунальному та приватному консультативно-діагностичних центрах. Соціологічне дослідження дозволило стверджувати, що існує необхідність нової оптимізованої моделі надання медичної допомоги для населення великого міста з використанням форм і моделей державно-приватного партнерства.
\end{abstract}

\section{COMPARISON OF INDICATORS OF ORGANIZATIONAL WORK IN PRIVATE AND MUNICIPAL NON-COMMERCIAL CONSULTATIVE-DIAGNOSTIC CENTERS}

\author{
A. O. Bob ${ }^{1}$, O. O. Chukur'1, I. V. Baloglanova ${ }^{2}$ \\ ${ }^{1}$ I. Horbachevsky Ternopil National Medical University \\ ${ }^{2}$ Mykolaiv Regional Oncology Dispensary
}

\begin{abstract}
The comparative analysis of the organization of secondary outpatient care to the adult population of Mykolaiv was carried out in municipal and private consultative and diagnostic centers. Sociological research has suggested that there is a need for a new optimized model of health care for the population of a large city using the forms and models of public-private partnership.
\end{abstract}

Вступ. У світовій практиці з'явилось і починає відігравати все більш важливу роль державно-приватне партнерство (ДПП) як форма взаємодії держави і приватного бізнесу [2]. Зростання інтересу до дПП пояснюється тим, що у багатьох країнах воно дозволяє ефективно вирішувати вагомі соціальні та економічні проблеми шляхом об'єднання ресурсів державного та приватного секторів [1]. В Україні поступово формуються нові економічні відносини, а заклади охорони здоров'я, функціонуючи за умов обмежених ресурсів, недосконалості управлінських і економічних механізмів, підтримують кризовий стан системи, що й вимагає пошуку нових управлінських рішень та економічних інструментів, які ґрунтуються на принципах ДПП.

Основна частина. у 2019 р. у м. Миколаєві за спеціально розробленою програмою проведено дослідження задоволеності населення медичною допомогоюу комунальному і приватному консультативно-

(с) А. О. Боб, О. О. Чукур, І. В. Балогланова, 2020 діагностичних та лікувальних центрах (КДЛЦ) із метою подальшого їх порівняльного аналізу. Соціологічне дослідження здійснювали шляхом анкетування пацієнтів, які звернулись до комунального (37осіб) і приватного (39 пацієнтів) КДЛЦ м. Миколаєва. Обидві вибірки були якісно та кількісно репрезентативними. Анкети заповнювали респонденти анонімно. Опитування пацієнтів проводили за спеціально розробленою анкетою, яка містила 21 питання і 61 підпитання. Статистична обробка матеріалів соціологічного дослідження передбачала використання методів статистичного групування, табличного зведення, аналізу абсолютних і відносних рядів розподілу, оцінку статистичної вірогідності відмінностей результатів соціологічного опитування респондентів у комунальному і приватному КДЛЦ (за критерієм Пірсона $\chi^{2}$ ). Аналіз матеріалів проведеного дослідження дозволив визначити статево-віковий склад пацієнтів комунального та приватного КДЛЦ, здійснити порівняльний аналіз 
їх розподілу за соціальним, матеріальним станом, рівнем освіти, а також вивчити їх задоволеність отриманою у КДЛЦ медичною допомогою.

Встановлено, що серед пацієнтів як комунального, так і приватного діагностичних центрів переважали жінки $((62,7 \pm 2,3) \%$ та $(55,8 \pm 2,5)$ \% відповідно). Віковий склад пацієнтів у комунальному і приватному КДЛЦ не мав суттєвих відмінностей. У комунальному центрі питома вага вікової групи 18-30 років склала $(19,9 \pm 1,9) \%$; 31-59 років - $(42,3 \pm 2,4) \%$, а старше працездатного віку (60 і більше) - $(37,8 \pm 2,3) \%$. У приватному, відповідно, $(19,9 \pm 2,0) \% ;(47,7 \pm 2,5) \% ;(32,3 \pm 2,4) \%$ (рис. 1$)$.

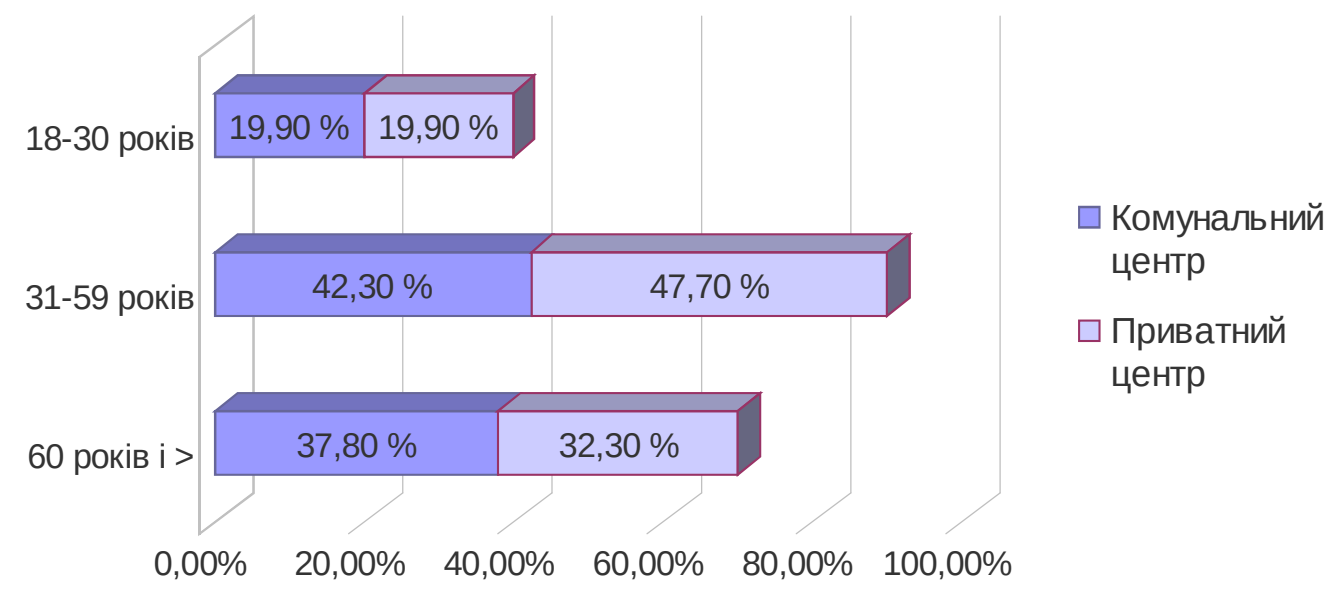

PUC. 1. Віковий склад пацієнтів у комунальному і приватному консультативно-діагностичних центрах.

При проведенні соціологічного дослідження важливе значення має освітній рівень опитаних, від якого значною мірою залежить санітарна культура, медична активність респондентів, а також їх задоволеність наданою медичною допомогою. Частка осіб, які мали вищу освіту, склала майже половину $((48,1 \pm 2,4) \%)$ серед пацієнтів комунального і більшість $((66,9 \pm 2,4) \%)$ серед пацієнтів приватного КДЛЦ. Вагомою була також питома вага осіб, які мали спеціальну середню освіту $((39,6 \pm 2,3) \%$ та $(26,8 \pm 2,2) \%$ відповідно). За соціальною належністю розподіл респондентів у комунальному та приватному КДЛЦ суттєво відрізнявся, $(24,7 \pm 2,1) \%$ серед пацієнтів комунального КДЛЦ становили службовці, $(16,7 \pm 1,8) \%$ - пенсіонери, $(15,6 \pm 1,7) \%$ - робітники, $(12,6 \pm 1,6) \%$ - домогосподарки. Серед пацієнтів приватного центру найбільшу частку склали підприємці $((44,7 \pm 2,5) \%)$ та службовці $((30,1 \pm 2,3) \%)$. При аналізі результатів соціологічних опитувань вагоме значення має матеріальний стан респондентів, який суттєво впливає на їхнє ставлення до багатьох аспектів організації медичного обслуговування, а також вибір для отримання медичної допомоги комунального або приватного КдЛЦ. Серед опитаних пацієнтів комунального КДЛЦ - $(41,9 \pm 2,4) \%$ мали доходи протягом останніх 12 місяців понад 2500 грн на місяць у розрахунку на одного члена сім'і, $(53,5 \pm 2,4) \%$ - від 1000 до 2500 грн і $(4,6 \pm 1,0) \%$ - менше 1000 грн. У приватному закладі частка пацієнтів, які мали доходи понад 2500 грн на місяць у розрахунку на одного члена сім'ї, становила $(78,3 \pm 2,1) \%$. Тобто розподіл пацієнтів комунального та приватного КДЛЦ за матеріальним станом суттєво відрізнявся ( $p<0,05)$.

Важливою складовою ефективної організації лікувально-діагностичного процесу в закладах охорони здоров'я $\epsilon$ скоординована взаємодія лікарів загальної практики - сімейної медицини та лікарів вузьких спеціальностей. Відповідно до діючих на сьогодні нормативних документів, пацієнтів мають направляти до лікарів вузьких спеціальностей лікарі загальної практики - сімейної медицини. За результатами нашого соціологічного дослідження, більшість $((66,1 \pm 2,3 \%))$ респондентів звернулась до комунального КДЛЦ самостійно і тільки третина $((33,9 \pm 2,3) \%)$ за направленням лікаря загальної практики - сімейної медицини (рис. 2). Маючи вільний вибір платних медичних послуг, пацієнти приватного діагностичного центру в $(90,4 \pm 1,5) \%$ звернулись самостійно $(p<0,05)$.

При організації роботи КДлЦ важливим $є$ забезпечення раціонального розподілу потоку пацієнтів за днями тижня і годинами прийому лікарів. Актуальною проблемою є організація прийому таким чином, щоб пацієнти не очікували у черзі тривалий час перед кабінетом лікаря. Дослідження показало, що витрати часу пацієнтів на очікування прийому в комунальних і приватних КДЛЦ істотно відрізняються. При зверненні до лікарів лікування призначалось $(79,2 \pm 1,8) \%$ пацієнтів у комунальному і $(97,2 \pm 0,8) \%$ у приватному КДЛЦ. 


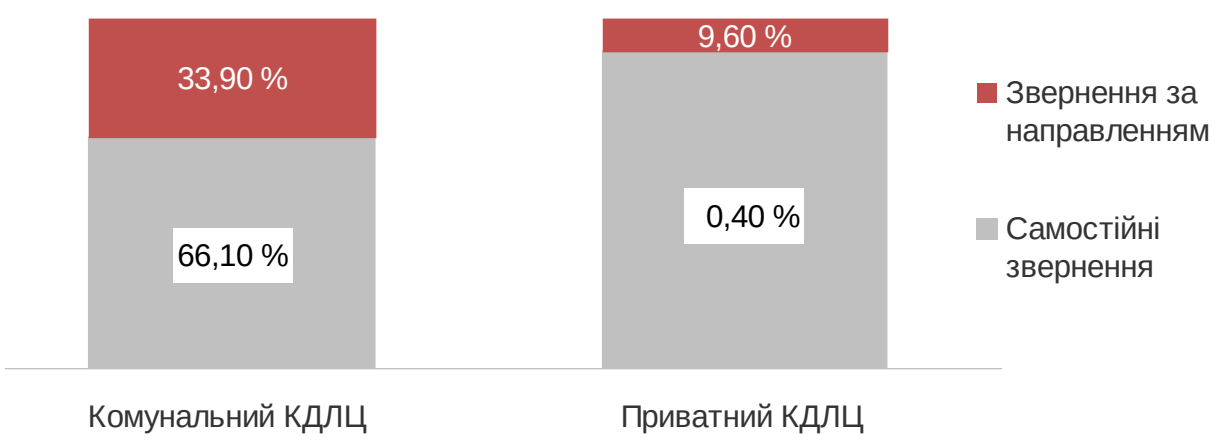

Рис. 2. Розподіл пацієнтів за кількістю звернень за медичною допомогою у комунальному і приватному консультативно-діагностичних центрах.

Це свідчить про те, що частині хворих $((20,8 \pm 1,8) \%)$ у комунальному КДЛЦ не потрібне було лікування і вони приходили за різними довідками, роз'ясненнями та под. (рис. 3).

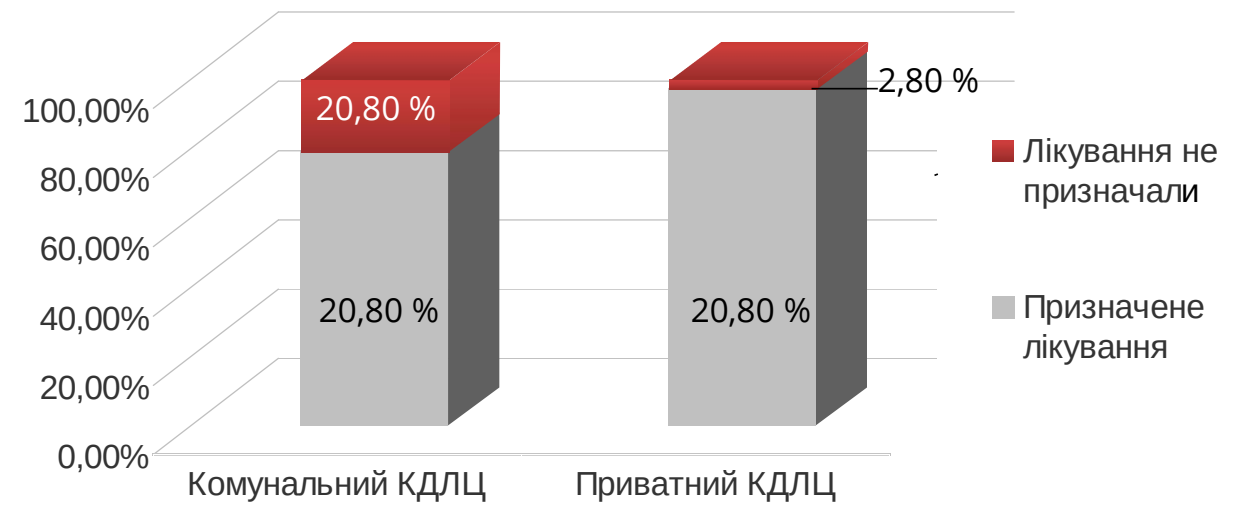

РИс. 3. Розподіл пацієнтів за кількістю призначення лікування у комунальному і приватному консультативно-діагностичних центрах.

При правильній організації роботи для таких пацієнтів повинен бути організований кабінет сестринського прийому, де пацієнти змогли би отримати різні довідки, не відволікаючи лікаря від прийому. $(8,2 \pm 1,3)$ \% пацієнтів у комунальному КДЛЦ були незрозумілі рекомендації надані лікарем після завершення лікування. Ймовірно дефіцит часу в лікарів на прийомі призводить до такої ситуації. Одним з ефективних методів активного динамічного спостереження за хворими є диспансерний метод. У комунальному КДЛЦ, згідно з результатами опитування, під диспансерним наглядом перебувало $(19,7 \pm 1,9) \%$ пацієнтів, а більшість $((80,3 \pm 1,9) \%)$ респондентів впевнено відповіла, що не перебуває під диспансерним спостереженням. У приватному закладі диспансерним наглядом охоплено $(86,6 \pm 1,7)$ \% пацієнтів. Таким чином, повнота охоплення диспансерним спостереженням істотно відрізняється.

Вітчизняними та зарубіжними дослідниками [3, 5, 7] доведено, що у зміцненні здоров'я населення про- відна роль належить профілактиці. Шляхи і методи вторинної профілактики більшості захворювань розроблені та можуть широко використовуватись для багатьох груп пацієнтів. $(51,0 \pm 2,4) \%$ респондентів у комунальному КДЛЦ відповіли, що вони добре знають питання профілактики свого захворювання, проте $(49,0 \pm 2,4)$ \% респондентів зізнались, що питання профілактики знають незадовільно. У приватному закладі, відповідно, $(92,7 \pm 1,3)$ \% і $(7,3 \pm 1,3)$ \% (рис. 4).

Рівнем сервісу в кабінетах комунального кдлЦ, естетичним оформленням приміщень залишились задоволені $(41,4 \pm 2,4) \%$ респондентів, а у приватному центрі - $(96,2 \pm 1,0) \%$. Відмінності у матеріально-технічному, сервісному забезпеченні та організації прийому в комунальних та приватних закладах позначаються на обслуговуванні пацієнтів та їх задоволеності отриманою допомогою (рис. 5). Задоволені якістю наданої медичної допомоги $(46,9 \pm 2,4) \%$ пацієнтів у комунальному КДЛЦ, у приватному - $(93,7 \pm 1,2) \%$ $(p<0,05)$. На існування проблем у забезпеченні якості

16 ISSN 2411-1597. МЕДСЕСТРИНСТВО. 2020. № 3 
Приватний КДЦ

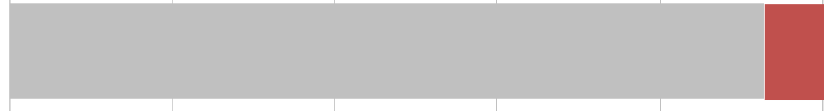

Комунальний КДЦ

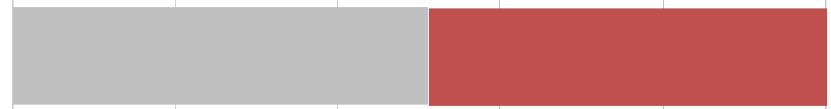

0

20

40

60

80

100

120

Обізнані щодо просрілактики Не достатньо знань щодо профрілактики

Рис. 4. Розподіл пацієнтів за методами вторинної профілактики захворювань у комунальному і приватному консультативно-діагностичних центрах.

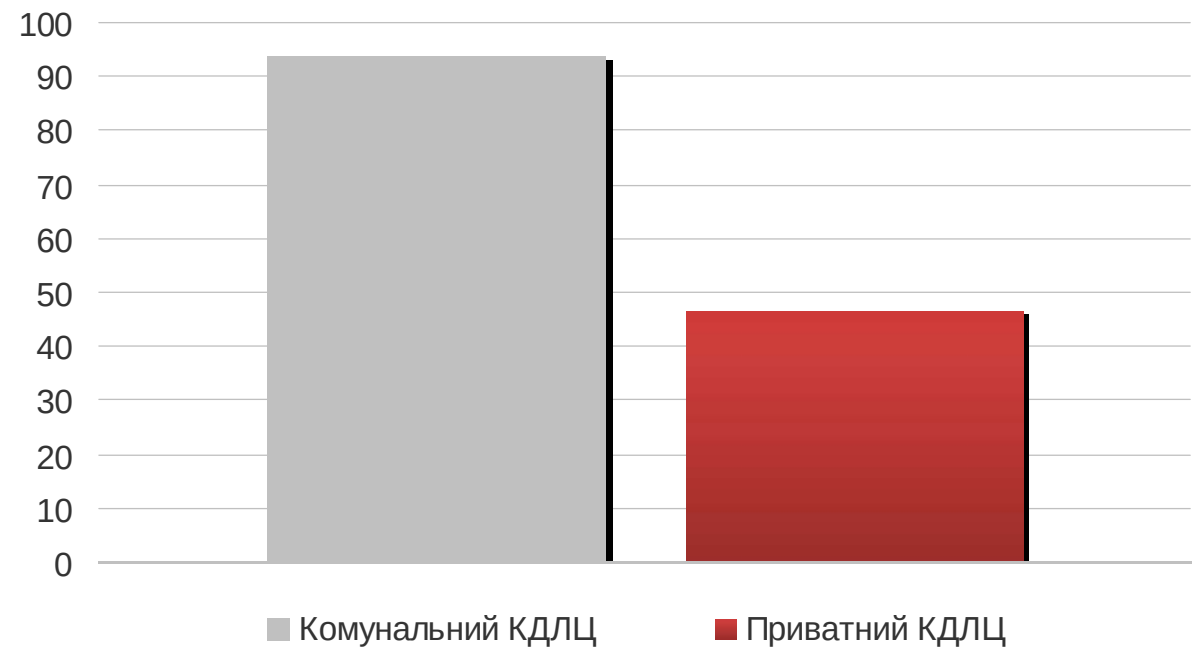

Рис. 5. Розподіл пацієнтів за рівнем задоволеності якістю наданої медичної допомоги у комунальному і приватному консультативно-діагностичних центрах.

та доступності амбулаторної допомоги, виявлених у ході соціологічних опитувань пацієнтів, вказує багато дослідників $[4,6,7]$.

Програмою соціологічного дослідження передбачено вивчення причин, через які пацієнти комунального КДЛЦ не звернулись до приватних закладів, а пацієнти приватного КДЛЦ не звернулись до комунальних закладів. На питання, адресоване пацієнтам комунального КДЛЦ: «Чому Ви не звернулись до при-

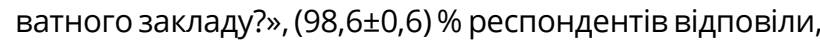
що дорогі послуги, $(92,2 \pm 1,3) \%$ - лікарі призначають дорогі медикаменти. На питання, поставлене пацієнтам приватного закладу: «Чому Ви не звернулись до комунального закладу?», $(98,0 \pm 0,7)$ \% відповіли, що все одно доведеться оплачувати послуги. Іншими причинами відмови у зверненні до комунального КДЛЦ було неуважне ставлення медичного персоналу $((91,7 \pm 1,4) \%)$, великі черги $((80,1 \pm 2,0) \%)$ та незадовіль- не оснащення комунальних закладів діагностичним обладнанням $((66,2 \pm 2,4) \%)$. Наявність платних послуг у комунальному КДЛЦ засвідчують і результати опитування пацієнтів даних закладів, які підтвердили, що їм доводилось платити за лабораторні аналізи $((90,8 \pm 1,4) \%)$, діагностичні обстеження $((97,3 \pm 0,8) \%)$, ін'єкції та інші маніпуляції $((95,2 \pm 1,1) \%)$.

Висновки. Проведене соціологічне дослідження дозволило здійснити порівняльний аналіз і дати характеристику стану організації вторинної амбулаторної допомоги дорослому населенню м. Миколаєва у комунальному та приватному КДЛЦ. Нами вперше проведено соціологічне дослідження задоволеності пацієнтів у комунальному КДЛЦ порівняно з приватним КДЛЦ. Встановлено, що на попит пацієнтів на медичні послуги впливає рівень доходів і платоспроможність населення, а також імідж медичного закладу (оснащення, кадри, технології, якість медичної 
допомоги). Показано, що за умов скорочення фінансових можливостей комунального сектора, значного зниження витрат держави на вторинну амбулаторну допомогу загострюються проблеми доступності та якості медичної допомоги. Результати проведеного дослідження засвідчили, що існуюча система надання вторинної амбулаторної допомоги у комунальних

\section{СПИСОК ЛІТЕРАТУРИ}

1. Амоша О. І. Удосконалення системи управління інноваціями як умова прискорення структурних реформ в Україні / О. І. Амоша, А. І. Землянкін, І. Ю. Підоричева // Економіка України. - 2015. - № 9. - С. 49-65.

2. Бондарєв Т. Реалізація державно-приватного партнерства у сфері охорони здоров'я України / Т. Бондарєв, Н. Поливка // Практика управління медичним закладом. 2014. - № 11. - С. 58-66.

3. Винницький Б. Досвід та перспективи впровадження державно-приватних партнерств в Україні та за кордоном / Б. Винницький, М. Лендел, Б. Онищук. - К. : К.І.С., 2018. - 146 c.

4. Шевчук Ю. В. Розвиток державно-приватного партнерства у контексті вдосконалення фінансового забезпечення сфери охорони здоров'я / Ю. В. Шевчук //
КДЛЦ м. Миколаєва не забезпечує сучасні потреби населення. Порівняльний аналіз роботи комунального та приватного КДЛЦ дає підстави стверджувати, що існує необхідність наукового обґрунтування нової оптимізованої моделі КДЛЦ для населення великого міста з використанням форм і моделей державно-приватного партнерства.

Економічний вісник університету. - 2017. - Вип. 33/1. С. 416-428.

5. Ярош Н. П. Порівняльний аналіз розвитку державних стандартів надання медичної допомоги в Україні та зарубіжних країнах / Н. П. Ярош // Україна. Здоров'я нації. - 2016. - № 4. - С. 62-71.

6. Brogaard L. The impact of innovation training on successful outcomes in public-private partnerships / L. Brogaard // Public Manage. Rev. - 2017. - Vol. 19, No. 8. P. 1184-1205.

7. Ciccone D. K. Arguing for a centralized coordination solution to the 365 public-private partnership explosion in global health / D. K. Ciccone // Glob. Health Promot. - 2018. Vol. 17, No. 2. - P. 48-51. 